\title{
Journal of Business And Management Review
}

homepage : https://profesionalmudacendekia.com/index.php/jbmr

\section{Relation Of Financial Literacy With Financial Attitude And Financial Behavior Among Tharu Woman Small Borrowers}

Rashesh Vaidya ${ }^{1 *}$

Ramesh G.C ${ }^{2}$

1 Siddhartha Vanasthali College of Management, Tribhuvan University, Kathmandu, Nepal.

2 Madhyabindu Multiple Campus, Tribhuvan University, Kawasoti, Nepal

\begin{tabular}{|c|c|}
\hline ARTICLE INFO & ABSTRACT \\
\hline $\begin{array}{l}\text { ISSN: 2723-1097 } \\
\text { Keywords: } \\
\text { Nepal, Tharu, } \\
\text { financial literacy, } \\
\text { financial attitude, } \\
\text { financial behavior, } \\
\text { women }\end{array}$ & $\begin{array}{l}\text { Tharu is an ethnic group indigenous to the Terai region of Nepal stretching from } \\
\text { east to west low-land of Nepal. The Tharu communities are normally residing in } \\
\text { most of the districts of the Terai belt of Nepal. The paper tries to find out the } \\
\text { relationship between financial literacy with financial attitude and financial } \\
\text { behavior among the women of the Tharu community of Nepal. Hence, the paper has } \\
\text { conducted a survey among the Tharu women living at Nawlapur District of } \\
\text { Gandaki Province of Nepal. The paper found that Tharu women who are in a saving } \\
\text { group, mainly focused on income saving and looking for an opportunity cost. } \\
\text { Similarly, Tharu women who are associated with a saving group, are mainly } \\
\text { concerned with the utilization of the credit, they had taken and worked for the } \\
\text { repayment of the credit in time. The paper also found that financial literacy has } \\
\text { highly influenced financial behavior among Tharu women of Nepal. At the same } \\
\text { time, the level of financial literacy is not seen as highly influencing the financial } \\
\text { attitude among the Tharu women of Nepal. }\end{array}$ \\
\hline
\end{tabular}

\section{Introduction}

In the course of everyday life, people make a variety of financial decisions about saving, investing, and borrowing. The global marketplace is increasingly risky and is becoming more vulnerable day by day. One of its main implications includes rising costs of goods and services that push people to make well-informed financial decisions (Lusardi \& Mitchell, 2011). A concern for the levels of financial literacy in society, as a whole, has grown considerably and is expected to grow even more attention in the future (Fox et al., 2005).

Wagner and Walstad (2018) opined that the global financial crisis raised the issue of financial literacy with higher priority. One of the reasons for the global financial crisis was the poor financial literacy of financial consumers. Normally, money management abolished the barter system; however, the concern of using money is closely linked with humans but difficult to pinpoint the date and context of the beginning of financial literacy. The relationship of knowledge and management of money is inseparable from

Journal of Business and Management Review Vol. 2 No. 102021 Page 665-676

DOI: $10.47153 /$ jbmr210.2312021

${ }^{*}$ Corresponding Author

Email address: vaidyarashesh@gmail.com 
each other. It is worthwhile to study the issue as a normal phenomenon that is close to a human being. Agenda of financial literacy was established and developed with economic history after being a financially informed, conscious, rational, and active person in a financial matter.

The awareness of the importance of financial education is gaining momentum among policymakers across the world's economies. Again, helping young people, by understanding their financial issues is quite important, as younger generations are likely to face ever- increasingly complex financial products and services. They are also more likely to bear more financial risks in adulthood than their parents, especially saving, planning for retirement, and covering their healthcare needs (OECD-INFE, 2011). The need for financial literacy has become increasingly significant with the deregulation of financial markets and the easy access to credit, the ready issue of credit cards, and the rapid growth in marketing financial products. Recognizing the importance of financial literacy, a growing number of countries have developed and implemented national strategies for financial education to improve the financial literacy of their population in general, often with a particular focus on the younger generation (Grifoni \& Messy, 2012).

Women face unique financial challenges as they need financial knowledge to build a financially secure future. Women's distinct challenges arise from life expectancies that are longer than men's, lower lifetime income than men, and career interruptions due to child-rearing. Women are likely to spend at least part of their retirement in widowhood, have different savings needs than men. Moreover, women are much less likely to plan, thus, less likely to be prepared for their retirement than men (Lusardi \& Mitchell, 2008). Hence, this shows a different attitude towards financial literacy even on gender basis.

Rajan et al. (2020) evaluated the relationship of financial literacy with saving and investment behavior of rural women of India. The study revealed that the women were conscious about the availability of investment avenues but were highly concerned on familiarity, safety and assured return from their investment. Further, lower financial skills combined with fewer available resources put women's financial security after retirement at risk.

Tharu are an ethnic group indigenous to the Terai region of Nepal stretching from east to west low-land of Nepal (Bista, 1971). The Tharu community of Nepal is maledominated, where a decision in a house is finalized by the head male member, the Tharu women were found opposing a girl to take a formal education while a father, who uses his elevated position in the family to let his daughter take a formal education (Chhetri, 2004). Though, the religious practices which indirectly suppress the female voice and have pre-dominated the Tharu community, the religion and culture had not been a barrier in context to liberate the female child. 
Specifically, this paper has three purposes. First, it tried to find out the position of financial literacy, financial behavior, and finally financial attitude among the Tharu women of Nepal. At the same time, the paper tries to find interrelationship among financial literacy, financial behavior, and financial attitude among the Tharu women of Nepal, who are also a small borrowers.

\section{Literature Review}

Mathivathani and Velumani (2014) come with a conclusion that the level of financial literacy among the women of rural are must be better to face with the financial malpractice as well as to tackle fraudulent occurring in the rural areas. Similarly, they argued that higher participation of women in an economy with proper financial literacy could even enhance the quality of the rural economy.

Sharma and Joshi (2015) found that the lack of financial knowledge among a women hinder them to make a better investment decisions and even brings obstacle in changing in an investment behavior. The study concluded that if a woman gets a better knowledge on finance, she could financial and social empower herself. Bonga and Mlambo (2016) identified thirty-two ways of enhancing women's financial literacy in context to Zimbabwe. The study found that the financially literate population becomes more aware of the financial products and enhance in stabilizing the financial market.

Banerjee and Sain (2016) concluded that self-help group formed by women could highly influence in enhancing the financial literacy level after being a part of the group. The study found that the level of financial literacy depends upon the financial needs and behavior of an individual. Rani (2017) found that financial inclusion among rural area women could be enhanced through an increment of financial literacy programs. The study further concluded that improving financial literacy levels among rural women could reduce their dependency on husbands to mediate the financial transaction.

Arora et al. (2018) found that the level of financial literacy among the rural area women could even impact directly in a macroeconomic level of the nation. An increasing financial literacy level of rural area women make them financial independent and could also contribute in the national income as well.

Murugesan and Manohar (2018) indicated that levels of financial literacy among homemakers were comparatively lower than that of working women. They also found that either spouse or in-laws were financial decision-makers in homemakers' families. At the same time, almost all working women have an awareness of banking services. Binod (2019) analyzed the level of financial literacy among women in Kerala, India. He found that financial literacy is composed of a combination of knowledge, skills, and dispositions that appear to be gender-related and that also appear to be related to access to varying types and levels of financial resources. The study found that women in Kerala have a 
reasonably fair level of financial literacy. Rai et al. (2019) found that there is a strong association of financial attitude and financial behavior with financial literacy of working women of Delhi than with financial knowledge.

\section{Method}

The paper has considered all the females from the Tharu community of Nepal as a population for the study. As the paper's objective is to determine the financial literacy level among the Tharu women of the Terai region of Nepal, it has adopted a purposive sampling technique. In context to Nepal, eight different sub-groups of Tharu are scattered around the Terai belt from east to west of Nepal. They are Rana Tharu, Kathariya Tharu, Sonha Tharu, Dangaura Tharu, Chitwan Tharu, Kochila Tharu, Danuwar and Lampucchwa Tharu (Lewis et al., 2014). Among the eight sub-groups, the paper has considered the sample of Tharu women from the community of Chitwan Tharu living around the Nawalpur district. Nawalpur district is a newly formed district of Gandaki Province after a breakdown of the previously known Nawalparasi district. It is a midpoint of the Mahendra Highway, i.e., stretched from east to west of Nepal. A total of 155 Tharu women are selected who are actively involved in certain financial activities from the Madhyabindu Municipality area of Nawalpur district. Hence, they are considered as a sample for the study. All the sample women are the small borrowers doing regular monetary transactions.

A questionnaire is based on the paper of Chaulagain (2018) to maintain criterionrelated validity. Basic information of the respondents and an opinion on mainly three factors, i.e., financial literacy, financial behavior, and financial attitude, were asked among the respondents. A five-point Likert scale has been used in a paper to measure opinion on respective factors, where score of ' 1 ' was allotted for 'highly positive' viewpoint and score of ' 5 ' for 'highly negative' viewpoint.

A pilot study among the 50 Tharu women borrowers was conducted to test the reliability of the questionnaire. Face-to-face interview with each respondent was done on the basis of a structured questionnaire to increase a response rate and put clarity about the questionnaire to the respondents in the Nepali language. After a Cronbach's Alpha test, an initial 40 items for three factors were limited to 12 items with a Cronbach's Alpha value of 0.618 reflecting a higher level of internal consistency.

After maintaining reliability and testing the consistency of the questionnaire, a further field survey among the remaining 105 respondents was conducted for the paper. The Statistical Package for the Social Science (SPSS) was used to analyze the raw data compiled from the field survey. Frequency tables with percent values were used for the presentation of information gathered about the respondents. Similarly, descriptive statistics were calculated for the remaining reliable opinions for the three variables of the paper, i.e., financial literacy, financial behavior, and financial attitude. At the same time,

668 | $\mathrm{P}$ a g e

Article's contents are provided on a Attribution-Non Commercial 4.0 Creative commons license.To see the complete license contents, please visit http://creativecommons.org/licenses/by-nc/4.0/ 
a correlation coefficient was calculated for the above variables to see the relationships among each other.

\section{Result and Discussion}

This section of the paper deals with the detail profiles of the respondents.

Table 1.Age Group of the Respondents

\begin{tabular}{llll}
\hline Age Group & Frequency & Percent & Cumulative Percent \\
\hline Below 20 & 8 & 5.20 & 5.20 \\
$20-30$ & 51 & 32.90 & 38.10 \\
$30-40$ & 46 & 29.70 & 67.70 \\
$40-50$ & 37 & 23.90 & 91.60 \\
50 and above & 13 & 8.40 & 100.00 \\
\hline Total & $\mathbf{1 5 5}$ & $\mathbf{1 0 0 . 0 0}$ & \\
\hline
\end{tabular}

Source: Field Survey, 2021

Table 1 illustrates the age group of the respondents. Of the total respondents' majority of them, i.e., 32.90 percent are from the age group of 20-30 years followed by the age group of 30-40 years. The least number of respondents were seen from the age group from below 20 years covering 5.20 percent.

Table 2.Marital Status

\begin{tabular}{llll}
\hline Marital Status & Frequency & Percent & Cumulative Percent \\
\hline Married & 119 & 76.80 & 76.80 \\
Unmarried & 36 & 23.20 & 100.00 \\
\hline Total & $\mathbf{1 5 5}$ & $\mathbf{1 0 0 . 0 0}$ & \\
\hline
\end{tabular}

Source: Field Survey, 2021

Table 2 illustrates the marital status of the respondents, where about 77 percent of them were seen married and remaining as unmarried.

Table 3.First Speaking Language

\begin{tabular}{llll}
\hline First Speaking Language & Frequency & Percent & Cumulative Percent \\
\hline Tharu & 59 & 38.10 & 38.10 \\
Nepali & 96 & 61.90 & 100.00 \\
\hline Total & $\mathbf{1 5 5}$ & $\mathbf{1 0 0 . 0 0}$ & \\
\hline
\end{tabular}

Source: Field Survey, 2021

Table 3 shows that the first speaking language of the respondents was seen Nepali for 61.90 percent, and the remaining was seen speaking Tharu.

The total respondents, 33.50 percent were seen daily wage earners, followed by farmers covering 24.50 percent. Similarly, 12.30 percent stated themselves as a job holder and around same percent of respondents stated engaged in small business and animal 
husbandry respectively. A single respondent introduced herself as a social worker, while three of them stated they are jobless.

Table 4.Occupation of the Respondents

\begin{tabular}{llll}
\hline Occupation & Frequency & Percent & Cumulative Percent \\
\hline Jobless & 3 & 1.90 & 1.90 \\
Farmer & 38 & 24.50 & 26.50 \\
Daily Wage Earner & 52 & 33.50 & 60.00 \\
Job Holder & 19 & 12.30 & 72.30 \\
Small Business & 18 & 11.60 & 83.90 \\
Social Worker & 1 & 0.60 & 84.50 \\
Animal Husbandry & 17 & 11.00 & 95.50 \\
Housewife & 7 & 4.50 & 100.00 \\
\hline Total & $\mathbf{1 5 5}$ & $\mathbf{1 0 0 . 0 0}$ & \\
\hline
\end{tabular}

Source: Field Survey, 2021

Table 5.Religion of the Respondents

\begin{tabular}{llll}
\hline Religion & Frequency & Percent & Cumulative Percent \\
\hline Hindu & 89 & 57.40 & 57.40 \\
Buddhism & 27 & 17.40 & 74.80 \\
Satya Bachan & 39 & 25.20 & 100.00 \\
\hline Total & $\mathbf{1 5 5}$ & $\mathbf{1 0 0 . 0 0}$ & \\
\hline
\end{tabular}

Source: Field Survey, 2021

More than 50 percent of the respondents, i.e. 57.40 percent stated to be Hindu, followed by Satya Bachan covering 25.20 percent. The remaining 17.40 percent stated they followed Buddhism.

Table 6.Household Size of the Respondents

\begin{tabular}{llll}
\hline No. of Family Members & Frequency & Percent & Cumulative Percent \\
\hline Two (2) & 3 & 1.90 & 1.90 \\
Three (3) & 13 & 8.40 & 10.30 \\
Four (4) & 34 & 21.90 & 32.30 \\
Five (5) & 48 & 31.00 & 63.20 \\
Six (6) & 29 & 18.70 & 81.90 \\
Seven (7) & 18 & 11.60 & 93.50 \\
Eight (8) & 9 & 5.80 & 99.40 \\
Nine (9) & 1 & 0.60 & 100.00 \\
\hline Total & $\mathbf{1 5 5}$ & $\mathbf{1 0 0 . 0 0}$ & \\
\hline
\end{tabular}

Source: Field Survey, 2021

The family size for the respondents ranged from two members to nine members in a family. Nevertheless, 31 percent had stated that the family size is of five members in a family. 
Table 7.Monthly Income of the Respondents

\begin{tabular}{llll}
\hline Income Range & Frequency & Percent & Cumulative Percent \\
\hline Below NPR 5,000 & 3 & 1.90 & 1.90 \\
NPR 5,000- NPR 10,000 & 59 & 38.10 & 40.00 \\
NPR 10,000-NPR 15,000 & 68 & 43.90 & 83.90 \\
NPR 15,000-NPR 20,000 & 22 & 14.20 & 98.10 \\
NPR 20,000 and above & 3 & 1.90 & 100.00 \\
\hline Total & $\mathbf{1 5 5}$ & $\mathbf{1 0 0 . 0 0}$ & \\
\hline
\end{tabular}

Source: Field Survey, 2021

Tharu women have been generating income that is being sufficient for their sustainable livelihood. Though, the earning at the range of NPR 10,000 to NPR 15,000 was seen the most among the respondents covering 43.90 percent.

Table 8.Education Level of the Respondents

\begin{tabular}{llll}
\hline Education Level & Frequency & Percent & Cumulative Percent \\
\hline Illiterate & 61 & 39.40 & 39.40 \\
Literate & 54 & 34.80 & 74.20 \\
SEE (Class 10) & 17 & 11.00 & 85.20 \\
SLCE (11-12) & 17 & 11.00 & 96.10 \\
Bachelor & 6 & 3.90 & 100.00 \\
\hline Total & $\mathbf{1 5 5}$ & $\mathbf{1 0 0 . 0 0}$ & \\
\hline
\end{tabular}

Source: Field Survey, 2021

Table 8 illustrates an education level of the respondents. About 40 percent of the respondents are seen illiterate, followed by 34.80 percent literate. Equal percent of the respondents were with a qualification Secondary Education Examination-SEE and School Leaving Certificate Examination-SLCE respectively. Only about 4 percent of the total respondents were with a bachelor degree.

\section{Attitude}

Descriptive Analysis of the Financial Literacy, Financial Behavior and Financial

\section{Financial Literacy}

Financial literacy is knowledge of basic economic and financial concepts, and an ability to use knowledge and skills to manage financial resources effectively for a lifetime of financial well-being (Hung et al., 2009).

An overall average score for financial literacy is seen 3.05 points, which is seen slightly above an average score. A measure of dispersion shows a positively skewed for 'demonstration effect'. Since, kurtosis values are all negative which reflect more data values are located near the mean and less data values are located on the tails. The opinion of respondents on financial literacy has been illustrated in Table 9 below: 
Table 9. Descriptive Statistics for Financial Literacy

\begin{tabular}{lcccccc}
\hline Items & Mean & $\begin{array}{c}\text { Std. } \\
\text { Deviation }\end{array}$ & Skewness & $\begin{array}{c}\text { Std. } \\
\text { Error }\end{array}$ & Kurtosis & Std. Error \\
\hline Income saving & 3.14 & 1.21 & -0.11 & 0.20 & -0.91 & 0.39 \\
Opportunity cost & 3.12 & 1.20 & -0.27 & 0.20 & -0.88 & 0.39 \\
Demonstration effect & 2.90 & 1.12 & +0.12 & 0.20 & -0.72 & 0.39 \\
\hline Overall Average & 3.05 & & & & & \\
\hline
\end{tabular}

Source: Field Survey, 2021

Sharma and Joshi (2015) found that a financial advisory was the concern among women for a better investment decision process. Similarly, Braunstein and Welch (2002) found that demonstration of program effectiveness is critical to maintaining the current level of interest in and resources devoted to enhancing financial literacy level. The major concern of the Tharu women is seen on the income saving and looking for opportunity cost. Similarly, demonstration effect is also seen effective for enhancing the financial literacy level in context to Tharu women of Nepal.

\section{Financial Behavior}

A consumer saving motive, saving investment motive, and investment motive influence mainly by the financial behavior and financial strategy of an individual (Nedorezova \& Ermolaev, 2020). In simple words, financial behavior involves the saving motives, spending habits, investment motive, and strategy of an individual. The opinion of respondents on financial behavior has been illustrated in Table 10 below:

Table 10. Descriptive Statistics for Financial Behavior

\begin{tabular}{lcccccc}
\hline Items & Mean & $\begin{array}{c}\text { Std. } \\
\text { Deviation }\end{array}$ & Skewness & $\begin{array}{c}\text { Std. } \\
\text { Error }\end{array}$ & Kurtosis & $\begin{array}{c}\text { Std. } \\
\text { Error }\end{array}$ \\
\hline Credit utilization & 3.19 & 1.25 & -0.16 & 0.20 & -0.88 & 0.39 \\
Credit repayment & 3.08 & 1.19 & +0.06 & 0.20 & -0.89 & 0.39 \\
$\begin{array}{l}\text { Review of financial } \\
\text { statement }\end{array}$ & 3.03 & 1.07 & -0.08 & 0.20 & -0.64 & 0.39 \\
$\begin{array}{l}\text { Increasing in income } \\
\text { Risk diversification }\end{array}$ & 2.99 & 1.29 & +0.05 & 0.20 & -1.07 & 0.39 \\
Multiple credit & 2.96 & 1.09 & +0.11 & 0.20 & -0.48 & 0.39 \\
Negotiation in saving & 2.95 & 1.24 & +0.08 & 0.20 & -0.96 & 0.39 \\
and credit & & & & & & \\
\hline Overall Average & 2.91 & 1.08 & -0.07 & 0.20 & -0.66 & 0.39 \\
\hline
\end{tabular}

Source: Field Survey, 2021

An overall average score for financial behavior is seen 3.02 points, which is seen slightly above an average score. Mathivathani and Velumani (2014) found that numerical skills with additional computer knowledge were a concern for improving financial 
behavior for the women of Tamilnadu, while credit utilization and credit repayment were seen first and second important aspects under the financial behavior for the Tharu women of Nepal. Review of financial statement is a third place of importance under the financial behavior is a good signal. A measure of dispersion shows four of the items positively skewed and remaining negatively skewed. Since, all the kurtosis value is seen negative, distribution is seen platykurtic.

\section{Financial Attitude}

A financial attitude is a certain response and evaluation made by an individual toward money and financial matters. Individuals' attitude toward money is a function of their personality. A financial attitude of an individual is heavily influenced by social expectations, demographic factors, economic circumstances, and the educational system (Alexandra et al., 2017). In simple words, a financial attitude is a judgmental statement from an individual concerning a money matter, which might be favorable or unfavorable. The opinion of respondents on financial behavior has been illustrated in Table 11 below:

Table 11. Descriptive Statistics for Financial Attitude

\begin{tabular}{lcccccc}
\hline Items & Mean & $\begin{array}{c}\text { Std. } \\
\text { Deviation }\end{array}$ & Skewness & $\begin{array}{c}\text { Std. } \\
\text { Error }\end{array}$ & Kurtosis & $\begin{array}{c}\text { Std. } \\
\text { Error }\end{array}$ \\
\hline Financial goal setting & 2.85 & 1.24 & +0.22 & 0.20 & -0.94 & 0.39 \\
Selection autonomy & 2.81 & 1.27 & +0.14 & 0.20 & -1.02 & 0.39 \\
\hline
\end{tabular}

Overall Average $\quad 2.83$

Source: Field Survey, 2021

An overall average score for financial attitude was seen 2.83 points but smaller than of financial literacy and financial behavior, which is seen slightly above an average score. A financial attitude among the Tharu women is not seen highly positive. Arora (2016) found the half of the women respondents from rural Rajasthan had a positive attitude towards financial planning and level of income had highly influenced in determining financial attitude, whereas, in context to Nepalese Tharu women are seen as highly focused on financial goal setting and work autonomously concerning financial matters. A measure of dispersion for the items is positively skewed. Since, all the kurtosis is seen negative, distribution is seen platykurtic.

\section{Relationship of Financial Literacy with Financial Behavior and Financial Attitude}

Nano (2015) found a significant statistical linkage among financial literacy, financial behavior and financial attitude. Similarly, Zaki et al. (2020) found that financial literacy and financial attitude have a significant relationship with financial behavior. In context to Nepal, Chaulagain (2018) found that there was a mix result in measuring relationship of financial literacy and attitude with financial behavior. 
The table of correlation matrix below shows a relationship between the variables in context to Nepalese Tharu women.

Table 12. Correlation Coefficient of Financial Literacy with Financial Attitude and Financial Behavior

\begin{tabular}{lll}
\hline Variables & Financial Literacy & Financial Behavior \\
\hline Financial Behavior & $+0.528^{* *}$ & \\
& $(0.000)$ & \\
Financial Attitude & $+0.160^{*}$ & $+0.562^{* *}$ \\
& $(0.046)$ & $(0.000)$ \\
\hline
\end{tabular}

** Correlation is significant at the 0.01 level (2-tailed).

* Correlation is significant at the 0.05 level (2-tailed).

Note: The values in parentheses are the $p$-value.

A very low degree of positive correlation $(+0.160)$ is between the financial literacy and financial attitude developed by the Tharu women of Nawalpur, which shows that the concept and knowledge level regarding finance has not much concern with the way the Tharu women make respond towards financial matters.

A high degree of positive correlation $(+0.528)$ is between financial literacy and financial behavior among the Tharu women of the Nawalpur district, which reflects that the knowledge on financial matters highly influences saving and investment motives among the Tharu women.

\section{Conclusion}

Women from a Tharu community of rural areas of Nepal have not many concerns about financial literacy. They were mainly focused on income saving and looking for an opportunity cost, followed by a slight impact from demonstration effects. Similarly, Tharu women associated with a saving group are mainly concerned with the utilization of the credit. They worked or engaged in financial activities for the credit repayment in time. The paper revealed that the Tharu women want some financial freedom in their life. The Tharu women look forward to living a lifestyle with complete economic autonomy.

The paper also revealed that financial literacy has highly influenced financial behavior among Tharu women of Nepal. Similarly, the level of financial literacy has not seen highly influenced the financial attitude among the Tharu women of Nepal.

\section{References}

Alexandra, L., Erzsébet, N. \& Boglárka, Z. (2017). Financial personality types and attitudes that affect financial indebtedness. International Journal of Social Science and Economic Research, 02(09), 4687-4704.

Arora, A. (2016). Assessment of financial literacy amongst working Indian women. Business Analyst, 36(2), 219-237. 
Arora, B., Sharma, S. \& Pahwa, M.S. (2018). Empowering women through financial literacy in Rajasthan. International Journal of Computer Sciences and Engineering, 6(9), 20-22.

Banerjee, P. \& Sain, K. (2016). A case study on women empowerment and financial literacy through SHGs. International Journal of Research in Economics and Social Sciences, 6(11), 295-301.

Binod, A. (2019). Financial literacy among women in Kerala: A rural-urban comparison. International Journal of Humanities and Social Science Invention, 8(02), 23-28.

Bista, D. B. (1971)." Tharu". People of Nepal. Ratna Pustak Bhandar.

Bonga, W.G. \& Mlambo, N. (2016). Financial literacy improvement among women in developing nations: A case of Zimbabwe. Journal of Research in Business and Management, 4(5), 22-31.

Braunstein, S., \& Welch, C. (2002). Financial literacy: An overview of practice, research, and policy. Federal Reserve Bulletin, November (88), 445- 457.

Chaulagain, R.P. (2018). Relationship between financial literacy and behavior of small borrowers. NRB Economic Review, 30(1), 34-53.

Chhetri, N. (2004). Book Review: Daughters of the Tharu: Gender, Ethnicity, Religion, and the Education of Nepali Girls by Mary Ann Maslak. Comparative Education Review, 48 (3), 340-342. https:// doi.org/10.1086/423767

Fox, J., Suzanne, B., \& Jinkook, L. (2005).Building the case for financial education. The Journal of Consumer Affairs, 39(1), 195-214. https://doi.org/10.1111/j.1745-6606. 2005.00009.x

Grifoni, A. \& Messy, F. (2012). Current status of national strategies for financial education: A comparative analysis and relevant practices. OECD Working Papers on Finance, Insurance and Private Pensions, No. 16, OECD Publishing. https://doi.org/ 10.1787/5K9BCWCT7XMN-EN

Hung, A.A., Parker, A.M., \& Yoong, J.K. (2009). Defining and measuring financial literacy. Rand: Labor and Population Working Paper WR-708, 1-28.

Lewis, M. P., Simons, G.F., \& Fennig, C.D. (2014). Tharu, Rana: A language of Nepal. In Ethnologue: Languages of the World. SIL International.

Lusardi, A. \& Mitchell, O.S. (2008). Planning and financial literacy: How do women fare? American Economic Review, 98 (2), 413-417. https:// doi.org/10.1257/ aer.98.2.413

Lusardi, A. \& Mitchell, O.S. (2011). Financial literacy and retirement planning in the United States. Journal of Pension Economics and Finance, 10 (4), 509-525. https:// doi.org/10.1017/S147474721100045X

Mathivathani, V. \& Velumani, M. (2014). A study on financial literacy among rural women in Tamilnadu. Indian Journal of Applied Research, 4(12), 556-557.

Murugesan, R. \& Manohar, V. (2018). Financial literacy at household level among women in Vizianagaram Village. International Journal of Research and Analytical Reviews, 5(3), 25-29. 
Nano, D. (2015). The interrelationship between financial attitude, financial behavior and financial knowledge. International Journal of Business and Technology, 4(1), 71-77. https:// doi.org/10.33107/ijbte.2015.4.1.09

Nedorezova, E.S. \& Ermolaev, K.N. (2020). Factors and motives defining the financial behavior of households. European Proceedings of Social and Behavioral Sciences, 13651370. https:// doi.org/10.15405/epsbs.2020.03.196

OECD-INFE, (2011). Measuring financial literacy: Core questionnaire in measuring financial literacy. Questionnaire and Guidance Notes for Conducting an Internationally Comparable Survey of Financial Literacy. OECD International Network on Financial Education (INFE), 1-31.

Rai, K., Dua, S. \& Yadav, M. (2019). Association of financial attitude, financial behaviour and financial knowledge towards financial literacy: A structural equation modeling approach. FIIB Business Review, 8(1), 51-60. https://doi.org/10.1177/ 2319714519826651

Rajan, B., Kaur, N., Athwal, H.K., Rahman, A. \&Velmurugan, P.S. (2020).Financial literacy as a tool for stimulating the investment behavior of rural women: An empirical assessment. In Investment Strategies in Emerging New Trends in Finance. Intech Open Book Series. https://doi.org/10.5772/intechopen.94532

Rani, S.A. (2017). A study on the level of financial literacy among rural women in Virudhunagar District. International Journal of Advance Research and Innovative Ideas in Education, 3(2), 86-91.

Sharma, A. \& Joshi, B. (2015). Financial literacy of women and its effect on their investment choice decision. Global Journal of Research Analysis, 4(7), 191-192. https:// doi.org/10.36106/gira

Wagner, J. \& Walstad, W.B. (2018). The effects of financial education on short-term \& long-term financial behavior. The Journal of Consumer Affairs, 53(1), 234-259. https:// doi.org/10.1111/joca.12210

Zaki, U.R.A., Rosli, M.H., Yahya, N.F. \& Halim, H. (2020). The relationship of financial literacy and financial attitude towards financial behavior: An empirical finding. International Journal of Business and Economy, 2(4), 13-24. http://myjms.mohe. gov.my/index.php/ijbec 